\title{
Intestinal epithelial cells contribute to the enhanced generation of platelet activating factor in ulcerative colitis
}

\author{
L Ferraris, F Karmeli, R Eliakim, J Klein, C Fiocchi, D Rachmilewitz
}

\begin{abstract}
Generation of platelet activating factor by intestinal mucosal epithelial cells and lamina propria mononuclear cells was evaluated to elucidate the possible role of this mediator in the pathogenesis of inflammatory bowel disease. Epithelial and lamina propria mononuclear cells were isolated from surgical specimens from control, Crohn's disease, and ulcerative colitis patients. Platelet activating factor was extracted from highly purified cell preparations with $80 \%$ ethanol after stimulation with and without $0.2 \mathrm{uM}$ calcium ionophore A23187 and was measured by platelet aggregation assay. Both cell types generated platelet activating factor activity and this was generally comparable for epithelial and lamina propria cells. Basal and stimulated platelet activating factor activity of epithelial and lamina propria cells from ulcerative colitis but not Crohn's disease patients was appreciably higher than that of control. Stimulation with calcium ionophore increased appreciably platelet activating factor activity in lamina propria cells from all groups. In contrast, only epithelial cells from ulcerative colitis showed an appreciable increase after calcium ionophore induction. These results suggest that epithelial cells are important contributors to intestinal platelet activating factor generation under normal and inflammatory conditions and that epithelial cells actively play a part in the pathogenesis of ulcerative colitis. (Gut 1993; 34: 665-668)
\end{abstract}

The pathogenesis of inflammatory bowel disease is unknown and probably multifactorial, resulting from the interaction of a variety of different genetic, environmental, immunological, metabolical, and bacterial components.' Both local cells and soluble mediators participate in the intestinal inflammatory process. Until recently most of the attention had been focused on the function of the intestinal mucosal immune system and its secreted products as these are known to have defined regulatory and proinflammatory activities. ${ }^{23}$ Gut epithelial cells, however, have also been shown to play an active part in normal and inflamed intestine: epithelial cells probably interact closely with the underlying immune cells by displaying a unique antigen presenting activity. ${ }^{45}$ In addition, gut epithelial cells may be the focus of destruction by the action of mucosal mononuclear cells ${ }^{6}$ or a complement mediated process, ${ }^{7}$ express potential autoantigens, ${ }^{8}$ secrete abnormal mucins, ${ }^{9}$ or be metabolically abnormal. ${ }^{10}$
We reported recently that colonic mucosa from patients with ulcerative colitis produce high values of platelet activating factor (PAF)," a potent proinflammatory lipid mediator. ${ }^{12}$ Drugs of proved benefit to Crohn's disease and ulcerative colitis patients, including steroids, salazopyrine, and 5-aminosalicylic acid, inhibit its production in a dose dependent way, suggesting that PAF may play a part in the pathogenesis of inflammatory bowel disease." This study was carried out to understand better its role in intestinal inflammation and to investigate whether PAF production is also raised in Crohn's disease. Also, considering the increasing evidence that not only immune cells but also epithelial cells play a part in the synthesis of inflammatory substances, we investigated the cellular source of PAF using highly purified preparations of autologous epithelial cells and lamina propria mononuclear cells

\section{Methods}

\section{PATIENT POPULATION}

\section{Crohn's disease patients}

Twenty patients with Crohn's disease, admitted to the Cleveland Clinic Hospital for bowel resection treatment, were studied. The group included 12 women and eight men, ages ranging from six to 84 years. Four patients had only ileal involvement and 16 had ileocolic or colonic disease. At the time of resection most patients were receiving corticosteroids and sulphasalazine. Ileal segments were available from six patients and colonic segments from 14 patients

\section{Ulcerative colitis patients}

Nineteen patients with ulcerative colitis undergoing colectomy were also studied. Six women and 13 men with ages ranging from 14 to 66 years. Most patients were receiving corticosteroids and sulphasalazine.

\section{Control subjects}

Twenty five surgical control patients, admitted for bowel resection for malignant and nonmalignant conditions, were studied. Eighteen had adenocarcinoma of the large bowel, anywhere from the caecum to the rectum. Seven patients were women and 11 were men, and their ages ranged from 49 to 84 years. Seven patients (four women and three men, ages ranging from 40 to 73 years) had a variety of non-malignant conditions, including three with diverticular 
disease, two with villous adenoma, one with arteriovenous malformation, and one with rectal prolapse. All diagnoses were confirmed by clinical, macroscopical, and histological criteria. This project was approved in 1990 by the Research Committee of the Cleveland Clinic Foundation

\section{CELL ISOLATION}

\section{Lamina propria mononuclear cells}

All surgical specimens were obtained immediately after resection, opened longitudinally, rinsed, examined for gross morphological changes, and a representative full thickness sample obtained. Lamina propria mononuclear cells were isolated by a modification of the original technique of Bull and Bookman. ${ }^{13}$ This method has been reported in detail. ${ }^{14}$ In brief, the dissected intestinal mucosa is freed of mucus and epithelial cells in sequential steps with dithiothreitol (DTT) (Sigma Chemical Co, St Louis, Missouri) and ethylenediaminetetraacetate (EDTA), and then digested with collagenase and deoxyribonuclease (both from Worthington Biochemical Corp, Freehold, New Jersey). The resulting crude cell suspension is purified using a Ficoll-Hypaque gradient and resuspended in culture medium. Purity of lamina propria mononuclear cells was mean (SEM) $92(5 \%)$ and viability checked by $0.1 \%$ trypan blue exclusion was $85(5 \%)$. epithelial cells. Lamina propria mononuclear cells and epithelial cells were isolated from surgical specimens of patients with ulcerative colitis $(n=$ 14-16), Crohn's disease ( $n=$ 17-19), and control subjects $(n=17-22) . P A F$ was extracted before or after 30 minutes incubation with and without $0 \cdot 2$ uM of CaI, and its activity determined by platelet aggregation. Results are mean (SEM)

$\star$ Significantly different from controls and from Crohn's disease, $p<0.05$. solution, after which the strips were washed in Hanks's balanced salt solution (HBSS) and then gently stirred in a $1 \mathrm{mM}$ EDTA solution for two periods of 60 minutes to release the epithelial cells. The supernatants were centrifuged for five minutes at $500 \mathrm{rpm}$ and the epithelial cells contained in the pellets were treated with dispase
(Boehringer Mannheim Corp, Indianapolis, Indiana) at a concentration of $3 \mathrm{mg} / \mathrm{ml} \mathrm{RPMI}$ 1640 (Whittaker Bioproducts, Walkersville, Maryland). Epithelial cells from both EDTA stirrings were pooled, washed with RPMI, and placed in a tube with the dispase solution and $1 \mathrm{mg} / \mathrm{ml}$ deoxyribonuclease I (Worthington) in a total volume of $15 \mathrm{ml}$. The tube was then incubated in a $37^{\circ} \mathrm{C}$ water bath, vortexing every five minutes for 30 minutes. The entire suspension was then passed over a nylon wool column. At this point microscopical examination showed a single cell suspension consisting of epithelial cells and a small number of mononuclear and red blood cells. Viability was $95-100 \%$. Final purification of epithelial cells was achieved by running the cell suspension over a $40 \%$ Percoll (Pharmacia LKB Biotechnology, Inc. Piscataway, New Jersey) gradient (adjusted to $287 \mathrm{mmol}$ with HBSS and $2 \cdot 5 \%$ hydroxyethylipiperazine-ethanesulphonic acid (HEPES) buffer), spun at $1500 \mathrm{rpm}$ for 2 minutes. After the epithelial cells were equilibrated at the interface of the Percoll layer they were collected and washed twice in RPMI 1640. Cytospin preparations of purified epithelial cells were stained by immunoperoxidase to ascertain purity and contaminating mononuclear cells. Only cells with epithelial cell morphology were stained diffusely by the anti-keratin mononuclear antibody AE1/ AE3 (Boehringer Mannheim Corp). Their purity was $92 \cdot 2(1 \cdot 0 \%)$ and viability $98(2 \%)$. Contaminating lamina propria mononuclear cells were $2 \%$ as assessed by staining with a mononuclear antibody directed to a leucocyte common antigen (CD45RB) (Dako Corp, Carpinteria, California). There was no evidence of platelet contamination in the lamina propria mononuclear cell or epithelial cell preparations.

\section{CELL EXTRACTION}

Extraction of PAF from cells was done using a previously described method with some modifications." Autologous lamina propria mono-

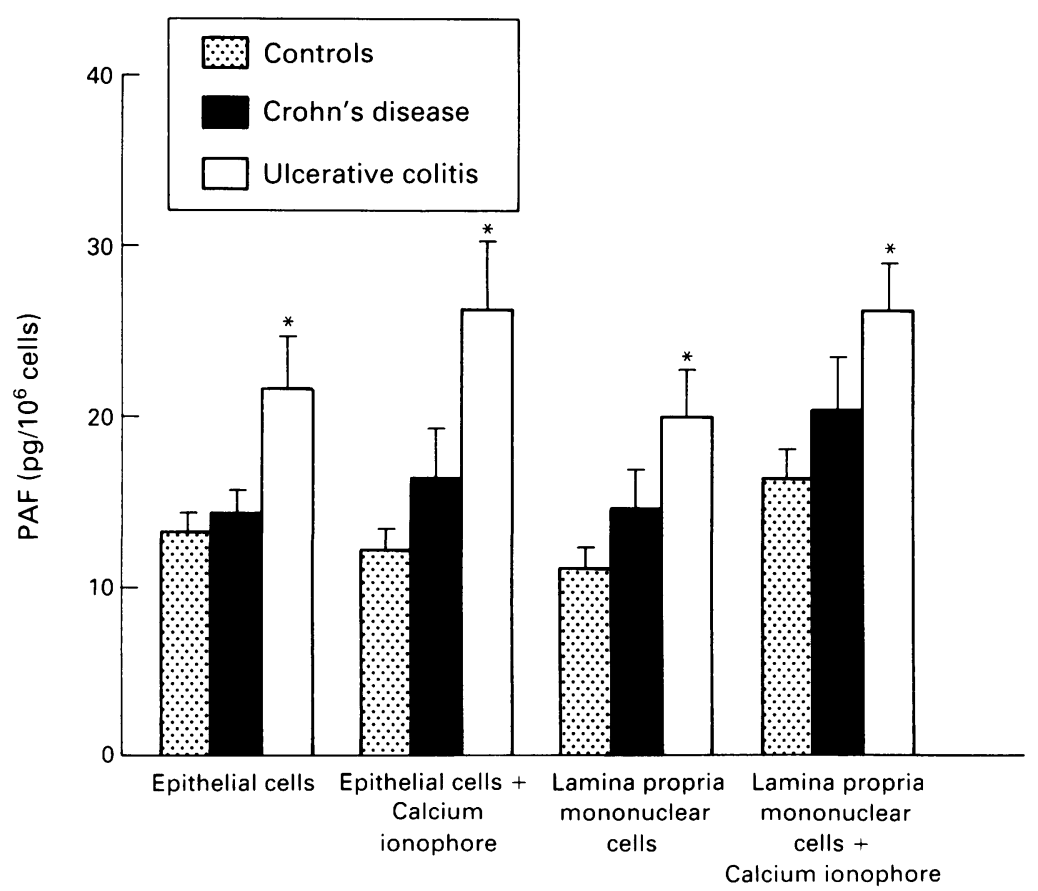
nuclear cells and epithelial cells were suspended at $1 \times 10^{6} / 0.5 \mathrm{ml}$ of Tyrode's buffer (137 mM $\mathrm{NaCl}, 1 \mathrm{mM} \mathrm{Na} 2 \mathrm{CO} 3,2.7 \mathrm{mM} \mathrm{KCl}, 0.5 \mathrm{mM}$ $\mathrm{NaH} 2 \mathrm{PO} 4,1 \mathrm{mM} \mathrm{MgCl} 2,1.3 \mathrm{mM} \mathrm{CaCl} 2,0 \cdot 1 \%$ glucose, $0.05 \%$ albumin, $\mathrm{pH} 7 \cdot 4$ ) and stimulated with $0.2 \mathrm{uM}$ calcium ionophore (CaI) A23187 (Sigma Chemical Co) at $37^{\circ} \mathrm{C}$ for 30 minutes. The suspensions were then centrifuged at $1500 \mathrm{rpm}$ for 10 minutes. Supernatants were collected while the cell pellets were suspended in $0.5 \mathrm{ml}$ $80 \%$ ethanol, and both were stored at $-70^{\circ} \mathrm{C}$ until assayed. Basal levels of PAF were obtained by testing the same cells to the above treatment without CaI.

\section{PLATELET PREPARATION}

Rabbit venous blood $(50 \mathrm{ml})$ was collected into Falcon tubes, mixed with $1 \mathrm{ml}$ of $0.2 \mathrm{M}$ ethylenediaminetetra-acetic acid, and centrifuged for 20 minutes at $1600 \mathrm{rpm} .{ }^{15}$ Plasma was transferred to another Falcon tube and centrifuged for 15 minutes at $3000 \mathrm{rpm}$. The platelet pellet was reconstituted with a washing buffer ( $\mathrm{pH} \mathrm{6.5)}$ containing $2.6 \mathrm{mM} \mathrm{KCl}, 1 \mathrm{mM} \mathrm{MgCl} 2,137 \mathrm{mM}$ 
$\mathrm{NaCl}, 12 \mathrm{mM} \mathrm{NaHCO} 3,0 \cdot 2 \mathrm{mM}$ ethyleneglycolbis (beta - aminoethylether) - N, N' - tetraacetic acid (Sigma Labs, Israel), $5.5 \mathrm{mM}$ glucose and $0.25 \%$ gelatine, and centrifuged for 15 minutes at $3000 \mathrm{rpm}$. The platelet pellet was resuspended in the above buffer and treated with $0.1 \mathrm{mM}$ aspirin (Aspegic Lab, Egic, Amilly, France) for 15 minutes at room temperature, followed by another centrifugation of 15 minutes at 3000 $\mathrm{rpm}$. Platelets were resuspended in washing buffer at appropriate concentrations for platelet aggregation measurement. ${ }^{16}$

\section{AGGREGATION ASSAY}

PAF activity was measured by platelet aggregation using a Chrono-log Corporation aggregometer. Platelets were stirred in $400 \mathrm{ul}$ of buffer containing $2.6 \mathrm{mM} \mathrm{KCl}, 1 \mathrm{mM} \mathrm{MgCl} 2,137 \mathrm{mM}$ $\mathrm{NaCl}, 12 \mathrm{mM} \mathrm{NaHCO} 3,1.3 \mathrm{mM} \mathrm{CaCl} 2,5.5 \mathrm{mM}$ glucose, $0 \cdot 25 \%$ gelatine, $1 \mathrm{mM}$ creatine phosphate and $10 \mathrm{U} / \mathrm{ml}$ creatine phosphokinase $(\mathrm{pH} 7 \cdot 4)$.

\section{ANALYSIS OF DATA}

Statistical analyses were performed using Student's $t$ test for paired and unpaired data and non-parametric Mann-Whitney test. All data are expressed as mean (SEM). A probability of $\mathrm{p}<0.05$ was considered as statistically significant.

\section{Results}

PAF activity was present in extracts of both epithelial cells and lamina propria mononuclear cells, spontaneously, as well as after induction by $\mathrm{CaI}$ (Figure). In epithelial cells basal and stimulated activity was not significantly different between control and Crohn's disease cells, whereas epithelial cells from ulcerative colitis cells contained significantly $(p<0.05)$ higher PAF values than both control and Crohn's disease cells. Using lamina propria mononuclear cells similar results were obtained, with ulcerative colitis cells producing significantly $(p<0.05)$ higher PAF values than control and Crohn's disease cells.

Unstimulated PAF activity of control, Crohn's disease, and ulcerative colitis epithelial cells was found to be similar to that of lamina propria mononuclear cells when epithelial and mononuclear cells were compared. After stimulation, however, a different pattern of PAF induction was seen between epithelial cells and lamina propria mononuclear cells (Table). Control epithelial cells failed to respond to $\mathrm{CaI}$, while cells from both forms of inflammatory bowel disease augmented their PAF activity. Only those cells from ulcerative colitis, however, increased their activity significantly $(p<0.05)$ above that of unstimulated cells. In contrast, lamina propria mononuclear cells from all groups responded to $\mathrm{CaI}$ stimulation, the increase in PAF activity being similar among them and significantly greater when compared with that of unstimulated cells.

In patients with Crohn's disease basal PAF activity in epithelial cells isolated from ileal segments $(12 \cdot 6(1 \cdot 9) \mathrm{pg} / 10 \mathrm{mg}$ wet wt $(\mathrm{n}=6))$ was
Effect of calcium ionophore (CaI) on basal PAF activity

\begin{tabular}{|c|c|c|c|}
\hline & \multirow{2}{*}{$\begin{array}{l}\text { Basal PAF } \\
\text { activity }\left(p g / 10^{\circ}\right. \\
\text { cells })\end{array}$} & \multicolumn{2}{|c|}{ CaI stimulated PAF activity } \\
\hline & & Stimulated $(n)$ & Increase $(\%)$ \\
\hline \multicolumn{4}{|l|}{ Epithelial cells } \\
\hline Controls & $13 \cdot 2(1 \cdot 2)$ & $5 / 17$ & $0 \cdot 2(9-3)-x)(s)$ \\
\hline Crohn's disease & $14.0(1$ & $10 / 18$ & $32 \cdot 0(19 \cdot 0)$ \\
\hline Ulcerative colitis & $21 \cdot 6(3 \cdot 1)$ & $13 / 1$ & $29 \cdot 0(8 \cdot 1)^{\star}$ \\
\hline \multicolumn{4}{|c|}{ Lamina propria mononuclear cells } \\
\hline Controls & $11 \cdot 0(1 \cdot 3)$ & $16 / 21$ & $75 \cdot 0(26 \cdot 0)^{\star}$ \\
\hline Crohn's disea & $14 \cdot 6(2 \cdot 4)$ & $13 / 17$ & $75 \cdot 0(33 \cdot 0)^{\star}$ \\
\hline Ulcerative colitis & $20 \cdot 0(2 \cdot 8)$ & $13 / 15$ & $72 \cdot 0(27 \cdot 0)^{\star}$ \\
\hline
\end{tabular}

Lamina propria mononuclear cells and epithelial cells were isolated from surgical specimens of patients with ulcerative colitis, Crohn's disease, and from control subjects. PAF was extracted before and after 30 minutes incubation with $0.2 \mathrm{uM} \mathrm{CaI}$ and its activity determined by platelet aggregation. Percentage increase is expressed as mean of \% difference from PAF activity without stimulation in each subject. Results are mean (SEM).

${ }_{\star}$ stimulation in each subject. Results are mean (SEM). $\star=$ Significantly different from basal activity
$(\mathrm{p}<0 \cdot 05)$; Student's $t$ test for paired data.

similar to its activity in epithelial cells isolated from colonic segments $(15 \cdot 1(2 \cdot 0) \mathrm{pg} / \mathrm{mg}$ wet wt $(\mathrm{n}=12))$. Basal PAF activity was also similar in ileal and colonic lamina propria mononuclear cells $(13 \cdot 4(2 \cdot 4)(\mathrm{n}=6)$ and $15 \cdot 2(3 \cdot 4) \mathrm{pg} / \mathrm{mg}$ wet wt $(n=13)$, respectively). There was also no significant difference in stimulated PAF activity between ileal and colonic epithelial or lamina propria mononuclear cells (results not shown).

\section{Discussion}

The results of this study show that in normal human intestinal mucosa PAF activity is generated by both epithelial cells and lamina propria mononuclear cells. During inflammation PAF activity is differentially expressed, being significantly higher in ulcerative colitis but not in Crohn's disease cells when compared with control.

PAF is a proinflammatory lipid mediator shown to play a part in inflammatory conditions of the gut, such as pouchitis ${ }^{17}$ as well as in animal models of experimental bowel necrosis. ${ }^{18}$ In this study PAF generation was found to be increased both in epithelial cells and in lamina propria mononuclear cells of ulcerative colitis patients, thus confirming and expanding our previous finding of enhanced PAF generation by mucosal biopsy specimens of ulcerative colitis patients." PAF generation by examination of colonic biopsy specimens of patients with Crohn's colitis has not been previously evaluated. In this study of Crohn's disease colitis, however, PAF activity was not found to be significantly increased in epithelial cells and lamina propria mononuclear cells above the values of control cells. These results show again the differences in the possible pathogenesis of Crohn's disease and ulcerative colitis. Other differences have been previously described with respect to the generation of other inflammatory mediators. Whereas colonic generation of prostaglandin $\mathrm{E}_{2}$, protaglandin $I_{2}$, and thromboxane $B_{2}$ were all found to be enhanced in ulcerative colitis, ${ }^{19}$ in Crohn's disease colitis only the generation of PGE2 and TxB2 were increased. ${ }^{20}$ We have also reported differences in the generation of eicosanoids by peripheral blood mononuclear cells of patients with ulcerative colitis and Crohn's disease. In these cells enhanced generation of PGE2 and TxB2 was detected in Crohn's disease but not in 
ulcerative colitis. ${ }^{21}$ Additional distinctions between these two forms of inflammatory bowel disease exist with regard to the generation of interleukin 2 induced lymphokine activated killer cells $\mathrm{s}^{22}$ and production of intestinal soluble interleukin 2 receptor. ${ }^{23}$

The difference between the response of epithelial cells and lamina propria mononuclear cells to $\mathrm{CaI}$ in both diseases is further highlighted in this study. In both diseases, PAF generation by lamina propria mononuclear cells was significantly enhanced by CaI but only epithelial cells from ulcerative colitis significantly increased their PAF generation following stimulation. Taken together, these studies clearly show how a detailed evaluation of different cell types and mediators of inflammation and immunoregulation can separate Crohn's disease from ulcerative colitis. Despite some similarities, it seems increasingly likely that the pathogenic mechanisms of ulcerative colitis and Crohn's disease are distinct.

The most interesting finding in this study is the contribution of epithelial cells to the generation of PAF in the gut. In control subjects, as well as in patients with inflammatory bowel disease, basal PAF generation by epithelial cells is similar to that of lamina propria mononuclear cells. Evidence is accumulating to show that gut epithelial cells interact closely with adjacent mononuclear cells. Epithelial cells can present antigens and stimulate immune cells, ${ }^{4}$ and these, in turn, can modulate epithelial cells through the release of soluble mediators. ${ }^{24-26}$ The contribution of epithelial cells to the formation of the inflammatory mediators is probably selective. We have shown that both in ulcerative colitis and Crohn's disease their contribution to the enhanced mucosal generation of eicosanoids is negligible by comparison with that of lamina propria mononuclear cells. ${ }^{27}$ In contrast, the enhanced generation of interleukin 1 by inflamed colonic mucosa in patients with inflammatory bowel disease is exclusively because of the production by lamina propria mononuclear cells as epithelial cells do not synthesise this cytokine. ${ }^{28}$ It seems that under both normal and abnormal conditions tightly regulated mechanisms modulate the interaction and mutual mediator exchange between epithelial and immune mucosal cells.

In summary, the results of this study suggest that while PAF contributes to the pathogenesis of the inflammatory response in ulcerative colitis, it has less implications for Crohn's disease. Epithelial cells are an important component in the enhanced mucosal generation of PAF in ulcerative colitis, suggesting that, in addition to cells of the local immune system, epithelial cells play an important part in intestinal inflammation.

The authors thank the members of the Colon and Rectal Surgery and Pathology Departments, Cleveland Clinic Foundation, for supplying the surgical specimens. This work was supported by a grant from the National Institutes of Health (NIDDK 30399) and the Crohn's and Colitis Foundation of America, Inc.

1 Podolsky DK. Inflammatory bowel disease (first of two parts) NEngl f Med 1991; 325: 928-37.

2 Fiocchi C. Production of inflammatory cytokines in the intestinal lamina propria. Immunol Res 1991; 10: 239-46.

3 Boughton-Smith N, Pettipher R. Lipid mediators and cytokines in inflammatory bowel disease. Eur $\mathcal{F}$ Gastroenterol Hepatol 1990; 2: 241-5.

4 Mayer L, Shlien R. Evidence for function of Ia molecules on gut epithelial cells in man. $\mathcal{F} E x p M e d$ 1987; 166: 1471-83.

5 Mayer L, Eisenhardt D. Lack of induction of suppressor T cells by intestinal epithelial cells from patients with inflammatory bowel disease. 7 Clin Invest 1990; 86: 1255-60.

6 Shorter RG, McGill DB, Bahn RC. Cytotoxicity of mononuclear cells for autologous colonic epithelial cells in colonic diseases. Gastroenterology 1984; 88: 13-22.

7 Halstensen TS, Mollnes TE, Garred P, Fausa O, Brandtzaeg P. Epithelial deposition of immunoglobulin Gl and activated complement ( $\mathrm{C} 3 \mathrm{~b}$ and terminal complement complex) in ulcerative colitis. Gastroenterology 1990; 98: 1264-71.

8 Takahashi F, Das KM. Isolation and characterization of a colonic autoantigen specifically recognized by colon tissuecolonic autoantigen specifically recognized by colon tissueb Clin Invest 1985; 76: 311-8.

9 Podolsky DK, Isselbacher KJ. Composition of human colonic mucin. Selective alteration in inflammatory bowel disease. f Clin Invest 1983; 72: 142-53

10 Roediger WEW. The colonic epithelium in ulcerative colitis: An energy-deficiency disease? Lancet 1980; 2: 712-5.

11 Eliakim R, Karmeli F, Razin E, Rachmilewitz D. Role of platelet activating factor in ulcerative colitis. Gastroenterology 1988; 95: 1167-72.

12 Showell HJ, Bray MA. Platelet activating factor (PAF), an inflammatory misnomer - where are we today? Advances in Inflammation Research 1986; 11: 67-70.

13 Bull DM, Bookman MA. Isolation and functional characterization of human intestinal mucosal lymphoid cells. $\mathcal{F}$ Clin Invest 1977; 59: 966-74.

14 Fiocchi C, Battisto JR, Farmer RG. Gut mucosal lymphocytes in inflammatory bowel disease. Isolation and preliminary functional characterization. Dig Dis Sci 1979; 24: 705-17.

15 Mencia-Huerta JM, Lewis RA, Razin E, Austen KF. Antigen initiated release of platelet activating factor (PAF-acether) from mouse bone marrow-derived mast cells sensitized with monoclonal IgE. F Immunol 1983; 131: 2958-64.

16 Tence M, Polonsky J, Le Couedic JP, Benveniste J. Release, purification and characterization of platelet-activating facto (PAF). Biochimie 1980; 62: 251-9.

17 Chaussade S, Denizot Y, Valleur P, Nicoli J, Raibaud P, Guerre J, et al. Presence of PAF-acether in stool of patients with pouch ileoanal anastomosis and pouchitis. Gastroenterology 1991; 100: 1509-14.

18 Sun X-M, Hsueh W. Bowel necrosis induced by tumor necrosis factor in rats is mediated by platelet-activating necrosis factor in rats is mediated by

19 Ligumsky M, Karmeli F, Sharon P, Cohen F, Zor U, Rachmilewitz D. Enhanced thromboxane A2 and prostacyclin production by cultured rectal mucosa in ulcerative colitis and its inhibition by steroids and sulfasalazine. Gastroenterology 1981; 81: 444-9.

20 Hawkey CJ, Karmeli F, Rachmilewitz D. Imbalance of prostacyclin and thromboxane synthesis in Crohn's disease. Gut 1983; 24: 881-5.

21 Rachmilewitz D, Ligumsky M, Haimovitz A, Treves AJ. Prostanoid synthesis by cultured peripheral blood. Mononuclear cells in inflammatory diseases of the bowel. Gastroenterology 1982; 82: 673-9.

22 Kusugami K, Youngman KR, West GA, Fiocchi C. Intestinal immune reactivity to interleukin 2 differs among Crohn's disease, ulcerative colitis and control. Gastroenterology 1989; 97: 1-9.

23 Matsuura T, West GA, Klein JS, Ferrais L, Fiocchi C. Soluble interleukin 2, CD8 and $\mathrm{CD} 4$ receptors in inflammatory bowel disease. A comparative study of peripheral blood and intestinal mucosal levels. Gastroenterology 1992; 102: 2006-14.

24 Cerf-Bensussan N, Quaroni A, Kurnick JT, Bhan AK. Intraepithelial lymphocytes modulate Ia expression by intestinal epithelial cells. F Immunol 1984; 132: 2244-51.

25 Sollid LM, Kvale D, Brandtzaeg P, Markussen G, Thorsby E. Interferon-g enhances expression of secretory component, the epithelial receptor for polymeric immunoglobulins. f Immunol 1987; 138: 4303-6.

26 Salomon P, Pizzimenti A, Panja A, Reisman A, Mayer L. The expression and regulation of class II antigens in normal and inflammatory bowel disease peripheral blood monocytes and inflammatory bowel disease peripheral blood monocy

27 Zifroni A, Treves AJ, Sachar DB, Rachmilewitz D. Prostanoid synthesis by cultured intestinal, epithelial and mononuclear cells in inflammatory bowel disease. Gut 1983; 24: 659-64.

28 Simon PL, West GA, Rachmilewitz D, Fiocchi C. Investigation of interleukin 1 (IL1) activity in the intestinal mucosa of Crohn's disease (CD) and ulcerative colitis patients. Gastroenterology 1989; 96: A473. 